\title{
DOI 10.26886/2414-634X.1(37)2020.8
}

UDC 349.22

PROCESSAL ASPECTS OF LOCAL REGISTRATION AS AN

ELEMENT OF THE LABOR REGULATION SYSTEM

\section{Dmytro Sirokha, PhD of Law, Associate Professor}

https://orcid.org/0000-0003-2805-2278

Taras Shevchenko National University of Kyiv, Ukraine, Kyiv

The purpose of the article is to determine the essence of the procedural aspects of local rule-making. This goal determined the research objectives, which are: the determination of the signs of the local rule-making process, the identification of the stages of the local rule-making process and the stages that make it up. the practice of norm-setting of subjects of labor law is manifested in the relevant procedural legal relations for the implementation of activities for the preparation of drafts of local regulatory acts, their consideration, discussion, adoption and enforcement. The author concluded that the rulemaking process covers two stages: preparation of a normative act and its adoption, including 6 stages: 1) a legislative initiative; 2) development; 3) discussion; 4) approval; 5) adoption and 6) the entry into force of the norative act.

Key words: legal regulation, labor relations, local legal acts, stages of rule-making, stages of rule-making.

Дмитро Сіроха, кандидат юридичних наук, доцент, Процесуальні аспекти локальної нормотворчості як елемент системи регулювання праці / Київський національний університет імені Тараса Шевченка, Київ, Україна

Метою статті є визначення сутності процесуальних аспектів локальної нормотворчості. Вказана мета обумовила завдання дослідження, якими є: визначення ознак локального нормотворчого 
процесу, виокремлення етапів локального нормотворчого процесу та стадій, що його складають. практика нормотворчості суб'єктів трудового права виявляється у відповідних процесуальних правовідносинах щодо здійснення діяльності по підготовці проектів локальних нормативних актів, їх розгляду, обговорення, прийняття та введення в дію. Автором зроблено висновок, що процес нормотворчості охоплює два етапи: підготовку нормативного акту та його прийняття, які включають 6 стадій: 1) нормотворчої ініціативи; 2) розробки; 3) обговорення; 4) погодження; 5) прийняття та 6) набуття чинності нормативним акту.

Ключові слова: правове регулювання, трудові відносини, локальні правові акти, стадії нормотворчості, етапи нормотворчості.

Постановка проблеми. Жодна держава не може існувати без налагодженого управлінського механізму, який би забезпечував гармонійний розвиток та функціонування правової системи суспільства. Основу цього механізму складають правові акти, а від якості процесу законотворчості значною мірою залежить здатність правових актів регулювати суспільні відносини. Саме тому на сучасному етапі розвитку Української держави гостро постає проблема якості трудового законодавства, однією 3 найважливіших умов якого у процесі удосконалення нормативно-правової регламентації трудової сфрери України є встановлення системи певних вимог, що застосовуються при створенні проектів нормативно-правових актів органами централізованої та локальної нормотворчості у трудовій сфері. Вказане обумовлює актуальність визначення сутності актів локальної нормотворчості та їх значення для правового регулювання праці.

Аналіз останніх досліджень і публікацій. Проблеми визначення ролі та місця локальних нормативно-правових актів у регулюванні 
праці розглядали у своїх роботах В.С.Венедіктов, С. В. Венедіктов, І. М. Іншин, В. Л. Костюк, І. А. Красюк, С. С. Лукаш, Р. А. Майданник,

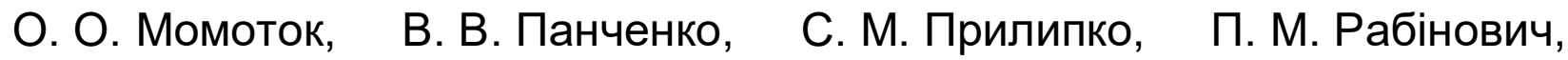
В. В. Форманюк, Є. О. Харитонов, Н. М. Хуторян, Г.І. Чанишева, О.М.Ярошенко та інші науковці. Разом з тим слід зазначити, що динамічні зміни змісту трудових відносин, викликані динамічним розвитком інформаційних технологій, а також активізація законотворчої роботи, наслідком якої має стати затвердження довгоочікуваного Трудового кодексу України, обумовлюють необхідність вироблення нового бачення значення актів локальної нормотворчості у регулюванні праці та слугують підтвердженням необхідності наукових розвідок за вказаним напрямом.

Формулювання мети статті та завдань. Метою статті $\epsilon$ визначення сутності локальної нормотворчості в їі процесуальному аспекті. Вказана мета обумовила завдання дослідження, якими є: визначення ознак локального нормотворчого процесу, виокремлення етапів локального нормотворчого процесу та стадій, що його складають.

Виклад основного матеріалу. Перш за все хотілося б сказати, що нормотворчий процес суб'єктів трудового права, з урахуванням концептуальних підходів, які склалися у науці трудового права, ми розуміємо як нормативно урегульований порядок діяльності державних та інших уповноважених органів по підготовці, прийнятті та документальному закріпленні юридичних рішень загального або індивідуального характеру, в яких фріксуються суб'єкти процесу, їх права, обов'язки, шляхи виконання фрункцій, що на них покладені [1, с.103-104]. Виходячи із запропонованого визначення необхідно зробити акцент на тому, що діяльність по створенню системи внутрішньо узгоджених нормативно-правових актів України здійснюється різними державними органами. 
Як наслідок, найбільш розповсюдженими вимогами до нормотворчого процесу можна назвати: вимоги загального характеру, спеціально-юридичні та організаційно-технічні. Так, до вимог загального характеру нормотворчого процесу суб'єктів трудового права належать об’єктивна необхідність (актуальність) та стабільність нормативноправових актів. До спеціально-юридичних вимог - вимога конституційності, нормативності, системності, підзаконності нормативно-правових актів та дотримання порядку їх проходження (стадійність). Організаційно-технічні вимоги полягають у дотриманні правил оформлення нормативно-правових актів (юридична техніка) [2, c.78].

Локально-правове регулювання має свою специфіку, що визначена рамками конкретного підприємства, і має свій суворо обмежений суб'єктний склад, який надає регулюванню необхідну спрямованість. Нормотворчість локального характеру розглядається як особлива форма прояву юридичного процесу та передбачає послідовність і результативність.

Вказане дає змогу виокремити наступні ознаки локального нормотворчого процесу: по-перше, локальна нормотворчість повинна здійснюватися за наявності необхідних повноважень суб'єктів трудових правовідносин; по-друге, реалізація локальної нормотворчості повинна забезпечуватись за допомогою основ її здійснення та передбачати виваженість і результативність здійснення нормотворчості на локальному рівні; і, по-третє, локальна нормотворчість повинна передбачати правову реальність нормотворчих положень уповноважених суб'єктів трудового права.

Отже, нормотворення суб'єктів у сфері праці має свої особливі ознаки, як-то: підзаконний характер - видання на основі і з метою реалізації Конституції і законів України; спеціальна компетенція - 
видається органами , що наділені спеціальною компетенцією, видання з метою реалізації і конкретизації актів вищестоящих органів [3, с.28]; як уточнення і подальший розвиток першої ознаки - менша юридична сила порівняно з актами вищих органів держави; вирішення питань, які мають переважно внутрішнє значення для певного підприємства(розповсюдження загалом лише на осіб та організації в межах даної структури).

Таким чином, при розробці проектів нормативних актів в галузі трудового права слід виходити з необхідності поліпшення правового регулювання галузевого управління, вдосконалення системи нормативних актів, впорядкування раніше виданих, створення, зміни, доповнення чи скасування організаційно-правового механізму реалізації чинного законодавства. Однак, безумовно, абсолютної свободи в нормотворчій діяльності корпоративних суб'єктів не може бути. В законодавстві мають передбачатися межі такої свободи шляхом встановлення певних принципів нормотворення та вимог до норматворчого процесу.

У процесуальному аспекті нормотворчість у сорері праці представляє собою певний процес, який складається 3 регламентованих нормами права послідовних організаційних дій суб'єктів трудових правовідносин, які послідовно переходять одна в одну, і направлені на створення централізованих та локальних нормативних актів. Відповідно, стадії нормотворчого процесу суб'єктів трудового права можна визначити як процес, направлений на закріплення нормативних приписів у сорері трудових правовідносин суб'єктами цих відносин, що передбачає структурно узгоджені дії для розроблення локальних нормативно-правових актів на рівні підприємства. 
Нормотворчий процес в галузі праці поділяється на два етапи: підготовку нормативного акту та його прийняття. Змістом першого етапу нормотворчого процесу $\epsilon$ здійснення комплексу науковоаналітичних, організаційних та інших дій, метою яких $€$ підготовка проекту нормативно акта [4]. Мета вважається досягнутою, коли проект розроблений. Змістом другого етапу є обговорення, зміна проекту, офріційне затвердження (прийняття) нормативного акту, а метою набрання ним чинності. Зазначені етапи включають наступні стадії.

Так, початковою є стадія прийняття рішення про необхідність врегулювання певної сфрери суспільних відносин шляхом створення правових норм та їх закріплення у нормативно-правових актах (стадія нормотворчої ініціативи), яка передбачає собою підготовчий процес та ініціативу суб'єктів трудового права, для запровадження дій в особі уповноважених на це органів щодо створення потенційних умов для упорядкування трудових відносин.

Другою є стадія розробки проекту нормативного акту. На цьому етапі здійснюється цілий комплекс обов'язкових підготовчих дій, що передують безпосередньому закріпленню певних потреб і інтересів у сорері праці. Проекти розробляються на підставі узагальнення практики застосування законодавства та локальних нормативних актів. Зокрема, розробка проекту локального нормативного акту можлива у вигляді підготовки:

1) нового локального нормативного акту;

2) зміни чи доповнення діючих локальних актів, тобто внесення до їх тексту нових приписів або заміна попередніх положень новими, які змінюють, уточнюють, розширюють або звужують зміст правового регулювання;

3) нової редакції (нового тексту) діючого локального нормативного акту, поліпшуючого зміст норм. 
Третьою є стадія обговорення проекту нормативного акту, на якій в проект локального нормативно-правового акта вносяться зміни, доповнення, висловлені фрахівцями, структурними підрозділами, представниками працівників. Дана стадія полягає в розробці адміністрацією та профрспілкою проекту колективного договору і винесення його на обговорення колективів цехів, відділень та інших підрозділів підприємства [5]. Обговорення підготовленого проекту сприяє подоланню та викоріненню неточностей шляхом дискусії між адміністрацією підприємства, органом профспілки та працівниками. Дана стадіє $€$ важливою з точки зору, запровадження в локальний нормативно-правовий метод спеціального характеру.

Четвертою є стадія погодження проекту нормативного акту, яка передбачає узгодження проекту акта з зацікавленими структурними підрозділами, окремими посадовими особами або представниками працівників. В межах даної стадії відбувається розгляд зібраних пропозицій на спільному засіданні ради трудового колективу та профрспілки за участю адміністрації.

П'ятою є стадія прийняття проекту нормативного акту, на якій підготовлений проект набуває юридичної сили, стає офріційним для даної організації правовим актом.

Шостою і завершальною $є$ стадія набуття чинності нормативним актом. Мета офріційного оприлюднення нормативно-правового акта інформування про прийнятий нормативно-правовий акт. Доведення прийнятого акту до відома працівників - необхідна умова його реалізації. Як наслідок, структурні підрозділи та посадові особи, які відповідальні за виконання локального нормативного акта, повинні ознайомити з його змістом виконавців та довести його зміст до відома працівників шляхом: його офріційного опублікування (централізовані нормативні акти); ознайомлення чи спільного узгодження. 
Висновки. Таким чином, практика нормотворчості суб'єктів трудового права виявляється у відповідних процесуальних правовідносинах щодо здійснення діяльності по підготовці проектів локальних нормативних актів, їх розгляду, обговорення, прийняття та введення в дію. Як наслідок, можна констатувати, що процес нормотворення в галузі праці охоплює два етапи: підготовку нормативного акту та його прийняття, які включають 6 стадій: 1) нормотворчої ініціативи; 2) розробки; 3) обговорення; 4) погодження; 5) прийняття та 6) набуття чинності нормативним акту.

Розробка і прийняття локальних актів сьогодні набули значного поширення. Деякі з них є результатом нормотворчої діяльності тільки роботодавця (наприклад, ті, що опосередковують технологічний процес в організації), інші - можуть прийматися роботодавцем за участю представників трудового колективу (спільно або за погодженням). Дана особливість $€$ однією із ключових ознак розрізнення локальних актів. Відповідно акти, які приймаються роботодавцем самостійно виражають одноособову волю роботодавця, інші носять договірний характер і виражають узгоджену волю роботодавця і трудового колективу. Це є свідченням того, що робота по створенню таких норм, яка провадиться всередині підприємства, є досить вагомою та значною для загального правового регулювання відносин у сфері праці.

\section{תimepamypa:}

1. Сіроха Д. (2019). Місце локальних нормативних актів у регулюванні праці в сучасних економічних умовах. Тенденції розвитку науки трудового права та права соціального забезпечення: тези доповідей учасників міжнародної наук.-практ. конф. (м. Київ, 2 квітня 2019 р.) / за ред. проф. М. І. Іншина, к. ю. н. І. С. Сахарук. Київ, C.102-105. 
2. Бобровник С.В.(1997). Нормотворча діяльність та проблеми систематизації законодавства. Правова держава. Вип. 8.С. 77-82.

3. Кириленко І. С. (2013). Локальна нормотворчість в системі юридичного процесу. Науковий вісник Херсонського державного університету. Серія: Юридичні науки. Вип. 3, Т. 1. С. 25-28.

4. Ухина С. В. (2006). Локальное нормотворчество (вопросы теории и практики): дис. ...канд. юрид. наук: 12.00.01, С. В. Ухина. - Коломна, 194 c.

5. Про колективні договори та угоди: Закон України. URL: https://zakon.rada.gov.ua/laws/show/3356-12 (дата звернення 11.01.2020).

\section{References:}

1. Sirokha D. (2019). Mistse lokalnykh normatyvnykh aktiv u rehuliuvanni pratsi $v$ suchasnykh ekonomichnykh umovakh. Tendentsii rozvytku nauky trudovoho prava ta prava sotsialnoho zabezpechennia: tezy dopovidei uchasnykiv mizhnarodnoi nauk.-prakt. konf. (m. Kyiv, 2 kvitnia 2019 r.), za red. prof. M. I. Inshyna, k. iu. n. I. S. Sakharuk. Kyiv, S.102-105 [in Ukrainian].

2. Bobrovnyk S. V. (1997). Normotvorcha diialnist ta problemy systematyzatsii zakonodavstva. Pravova derzhava. Vyp. 8.S. 77-82 [in Ukrainian].

3. Kyrylenko I. S. (2013). Lokalna normotvorchist v systemi yurydychnoho protsesu. Naukovyi visnyk Khersonskoho derzhavnoho universytetu. Seriia: Yurydychni nauky. Vyp. 3, T. 1. S. 25-28 [in Ukrainian].

4. Ukhyna S. V. (2006). Lokalnoe normotvorchestvo (voprosы teoryy y praktyky): dys. ...kand. yuryd. nauk: 12.00.01, S. V. Ukhyna. Kolomna, $194 \mathrm{~s}$. 
5. Pro kolektyvni dohovory ta uhody: Zakon Ukrainy. URL: https://zakon.rada.gov.ua/laws/show/3356-12 (data zvernennia 11.01.2020) [in Ukrainian].

Citation: Dmytro Sirokha (2020). PROCESSAL ASPECTS OF LOCAL REGISTRATION AS AN ELEMENT OF THE LABOR REGULATION SYSTEM. Innovative Solutions in Modern Science. 1(37). doi: 10.26886/2414-634X.1(37)2020.8

Copyright: Dmytro Sirokha (․ 2020. This is an openaccess article distributed under the terms of the Creative Commons Attribution License (CC BY). The use, distribution or reproduction in other forums is permitted, provided the original author(s) or licensor are credited and that the original publication in this journal is cited, in accordance with accepted academic practice. No use, distribution or reproduction is permitted which does not comply with these terms. 